\title{
YESUS: SOSOK GURU AGUNG (KOMPETENSI DAN PROFESIONALITAS DASAR GURU PAK)
}

\author{
Magdalena Grace K.Tindagi
}

\section{PENDAHULUAN}

Seorang guru perlu mengikuti berbagai lokakarya, penataran, dan studi di jenjang yang lebih tinggi, bahkan bersertifikat sebagai pendidik, seperti yang sedang digiatkan oleh Pemerintah untuk menaikkan mutu seorang pendidik. Dengan maksud agar tercapai tujuan Pendidikan Nasional sebagaimana yang tersirat di dalam UUD 1945, yakni: pertama, Pendidikan sebagai upaya untuk mencerdaskan kehidupan bangsa. Kedua, Pendidikan sebagai hak seluruh bangsa.

Wina Sanjaya mengatakan bahwa ada empat hal yang dapat dikaji dari Undang-Undang tersebut yakni: 1) Pendidikan adalah usaha sadar dan terencana, hal ini berarti proses pendidikan adalah proses yang bertujuan, sehingga segala sesuatu yang dilakukan guru dan murid diarahkan pada pencapaian tujuan. 2) Proses pendidikan yang terencana itu diarahkan untuk mewujudkan suasana belajar dan proses pembelajaran. 3) Suasana belajar itu diarahkan agar peserta didik dapat mengembangkan potensi dirinya, itu berarti pendidikan adalah upaya pengembangan potensi murid atau peserta didik. Jadi tugas pendidikan adalah mengembangkan potensi yang dimiliki anak didik. 4) Akhir dari proses pendidikan adalah kemampuan anak untuk memiliki kekuatan spiritual keagamaan, pengendalian diri, kepribadian, kecerdasan, akhlak mulia, serta keterampilan yang diperlukan dirinya, masyarakat, bangsa dan Negara. ${ }^{1}$

Tuntutan kebijakan pendidikan di Indonesia tertuang dalam UU Guru dan Dosen No.14 tahun 2005, pasal 1 dengan rumusannya: "Guru adalah pendidik profesional dengan tugas utama mendidik, mengajar, membimbing, mengarahkan, melatih, menilai, dan mengevaluasi peserta didik pada pendidikan anak usia dini PADjalur pendidikan formal, pendidikan dasar, dan pendidikan menengah" ${ }^{2}$. Guru seperti ini harus mempunyai kualifikasi formal. Secara khusus, bagi guru PAK dituntut juga untuk memiliki profesionalitas ini.

Salah satu cara yang efektif untuk menggali serta meningkatkan kemampuan tersebut adalah dengan mengevaluasi diri sendiri. Bentuk evaluasi pada guru PAK itu mengacu pada sosok Yesus sebagai Guru Agung.

\footnotetext{
${ }^{1}$ Wina Sanjaya, Kurikulum dan Pembelajaran, (Jakarta: Prenada Media, 2011), 2

2 B.S. Sidjabat, Mengajar secara Profesional, (Bandung: Yayasan Kalam Hidup, 2008), 30
} 


\section{BAB I \\ KOMPETENSI PROFESIONAL GURU}

Guru merupakan salah satu faktor penentu tinggi-rendahnya mutu pendidikan. Keberhasilan penyelenggaraan pendidikan sangat ditentukan oleh sejauh mana kesiapan seorang guru dalam mempersiapkan peserta didiknya melalui kegiatan belajar-mengajar. Posisi strategis guru untuk meningkatkan mutu hasil pendidikan sangat dipengaruhi oleh kompetensi professional guru dalam mengajar, juga sejauh mana tingkat kesejahteraannya. ${ }^{3}$

\section{Pengertian Kompetensi}

Departemen Pendidikan Nasional mendefinisikan kompetensi sebagai pengetahuan, keterampilan, sikap, dan nilai-nilai yang diwujudkan dalam kebiasaan berpikir dan bertindak. ${ }^{4}$ Dalam definisi ini karakteristik mendasar dalam kepribadian individu (personal karakteristik) ditunjukkan oleh perwujudan kebiasaan berpikir dan bertindak. Searah dengan itu menurut Spencer and Spencer bahwa kompetensi merupakan karakteristik mendasar seseorang yang berhubungan timbal balik dengan suatu kriteria efektif dan atau kecakapan terbaik seseorang dalam pekerjaan atau keadaan. ${ }^{5}$ Pernyataan Johson yang dikutip oleh Sanjaya bahwa: "competency as rational performance which satisfactorily meets objective for desired condition.. ". 6 Dengan demikian, suatu kompetensi ditunjukkan oleh penampilan atau unjuk kerja yang dapat dipertanggungjawabkan (rational) dalam upaya mencapai tujuan.

\section{Tipe-tipe Kompetensi}

Spencer and Spencer membahas lima tipe kompetensi, yakni:

a) Motivasi adalah sesuatu yang dimiliki seseorang untuk berpikir secara konsisten, atau keinginan untuk melakukan suatu aksi. Contoh: seseorang yang mempunyai motivasi, akan menentukan tantangan untuk dirinya sendiri, kemudian bertanggung jawab untuk mencapai tantangan tersebut dan menggunakan

${ }^{3}$ John M. Nainggolan, Menjadi Guru Kristen, (Bandung: Generasi Info Media, 2007), 26

4 ........, Kerangka Dasar dan Struktur Program, (Jakarta: Departemen Pendidikan Nasional, 2004), 79

${ }^{5}$ L.M. Spencer and S.M. Spencer, Competence at Work: Models for Superior Perfomance, (New York: John Williey and Sons. Inc, 1993), 9-11; Karakteristik mendasar berarti kompetensi tersebut cukup mendalam dan bertahan lama sebagai bagian dari kepribadian seseorang sehingga dapat digunakan untuk memprediksi tingkah laku seseorang ketika berhadapan dengan berbagai situasi dan tugas; Hubungan timbal balik artinya suatu kompetensi dapat menyebabkan atau memprediksi perubahan perilaku; Kriteria efektif menentukan dan memprediksi apakah seseorang bekerja dengan baik atau tidak dalam ukuran yang spesifik atau standar.

${ }^{6}$ Wina Sanjaya, Strategi Pembelajaran Berorientasi Standar Proses Pendidikan, (Jakarta: Prenada Media, 2011),17 Kompetensi merupakan perilaku rasional guna mencapai tujuan yang dipersyaratkan sesuai dengan kondisi yang diharapkan. 
outputnya untuk memperbaikinya. Motivasi bekerja secara intrinsik atau mulai dengan dirinya sendiri (self starting). Motivasi dapat menguasai pembawaan yang dapat memperkirakan apa yang dikerjakan seseorang dalam jangka panjang walaupun tanpa pengawasan yang ketat.

b) Pembawaan adalah karakteristik fisik yang merespon secara konsisten berbagai situasi atau informasi. Contoh: reaksi terhadap waktu dan sudut pandang yang baik adalah kompetensi bawaan dari seorang pilot pesawat tempur. Kontrol emosi diri dan inisiatif merupakan respon konsisten yang lebih kompleks. Kompetensi bawaan yang dapat mengontrol emosi dan menumbuhkan inisiatif, merupakan kompetensi dari seorang manajer yang berhasil.

c) Konsep diri adalah tingkah laku, nilai atau citraan (image) seseorang. Contoh: percaya diri. Seseorang yang percaya diri akan efektif pada berbagai situasi. Rasa percaya diri ini sudah menjadi bagian dari jati dirinya sehingga dapat diterapkan dalam berbagai situasi yang berbeda.

d) Pengetahuan adalah informasi khusus yang dimiliki seseorang. Contoh: ahli bedah memiliki pengetahuan mengenai syaraf dan tulang pada tubuh manusia. Pengetahuan merupakan kompetensi yang kompleks. Hasil tes pengetahuan sering salah dalam memperkirakan kinerja seseorang. Tes pengetahuan sering gagal mengukur pengetahuan dan keterampilan yang digunakan dalam hal bekerja. Hal ini disebabkan karena: 1) Tes yang digunakan adalah untuk mengukur ingatan seseorang. Padahal yang diperlukan adalah kemampuan mencari pengetahuan. 2) Tes pengetahuan mengukur respon seseorang terhadap pilihan-pilihan jawaban, bukan apa tindakannya dalam menggunakan pengetahuan tersebut. Kemampuan seseorang dalam menentukan pilihan jawaban, benar-benar sangat berbeda dengan kemampuan menentukan keberpihakan terhadap suatu situasi konflik, atau kemampuan memberikan argumen untuk diterima. Pengetahuan meramalkan apa yang dapat dikerjakan seseorang, bukan apa yang akan dikerjakan setelah tes.

e) Keterampilan adalah kemampuan untuk melakukan tugas secara fisik atau mental. Contoh: dokter gigi memiliki kemampuan fisik untuk menambal gigi tanpa merusak syaraf. Programmer computer memiliki kemampuan untuk

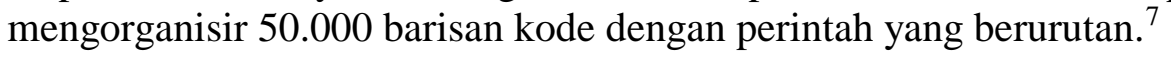

\footnotetext{
${ }^{7}$ L.M. Spencer and S.M. Spencer, Competence at Work:....., 9-11. Kelima kompetensi tersebut mempunyai implikasi praktis terhadap perencanaan sumber daya manusia. Keterampilan dan pengetahuan cenderung lebih tampak pada permukaan ciri-ciri seseorang, sedangkan konsep diri, pembawaan, dan motif lebih tersembunyi dan lebih mendalam serta merupakan pusat dari kepribadian seseorang.
} 


\section{Pengelompokan Potensi}

Selanjutnya Yulaelawati mengutip pendapat McClelland and Spencer yang mengelompokkan potensi ke dalam tiga kategori, yaitu pengetahuan, keterampilan, dan karakteristik personal, yang dijelaskan sebagai berikut:

a) Pengetahuan tentang fakta atau prosedur, seperti keanekaragaman makhluk hidup, anatomi tubuh manusia, berhitung, analisis keuangan, pelayanan dan jasa, serta computer literasi.

b) Keterampian merupakan keterangan kognitif atau perilaku, seperti bekerja sama, membangun jaringan, membentuk kekeluargaan, membangun pengertian, dan membuat orientasi terinci.

c) Karakteristik personal merupakan ciri pembawaan individu, misalnya kemampuan menyesuaikan diri, percaya diri, control diri, menanggulangi stress, menyelesaikan konflik, prakarsa, kemandirian, integritas, dan kesadaran interpersonal. ${ }^{8}$

\section{Ciri-ciri Bekerja secara Efektif}

Adapun ciri-ciri lain yang menunjukkan bahwa seseorang mampu bekerja secara efektif adalah:

\section{1) Bekerja secara Profesional}

Kata profesional berasal dari kata sifat yang berarti pencaharian, dan sebagai kata benda yang berarti orang yang mempunyai keahlian (guru, dokter, hakim). Arti pekerjaan yang bersifat profesional adalah pekerjaan yang hanya dapat dilakukan oleh mereka yang khusus dipersiapkan untuk itu, dan bukan pekerjaan yang dilakukan oleh mereka yang karena tidak memperoleh pekerjaan lain. ${ }^{9}$ Searah uraian ini ada lima konsep istilah yang berkaitan, yaitu profesi, profesional, profesionalisme, profesionalisasi, dan profesionalitas seperti yang dikutip oleh Kansil dari Sanusi sebagai berikut:

a) Profesi adalah suatu jabatan atau pekerjaan yang menuntut keahlian (expertise) dari anggotanya. Artinya tidak bisa dilakukan oleh sembarang orang yang tidak dilatih dan tidak disiapkan secara khusus untuk melakukan pekerjaan itu.

b) Profesional menunjuk kepada dua hal: (1) orang yang menyandang suatu profesi; (2) penampilan seseorang dalam melakukan pekerjaannya yang sesuai dengan profesinya.

\footnotetext{
${ }^{8}$ Ella Yulaelawati, Kurikulum dan Pembelajaran, (Bandung: Pakar Raya, 2004), 16
}

9 John. M. Nainggolan, Menjadi ....., 29 
c) Profesionalisme menunjuk kepada komitmen para anggota suatu profesi untuk meningkatkan kemampuan profesionalnya, dan terus menerus mengembangkan strategi-strategi yang digunakan dalam melakukan pekerjaan yang sesuai dengan profesinya.

d) Profesionalitas mengacu pada sikap para anggota profesi terhadap profesinya serta derajat pengetahuan dan keahlian yang mereka miliki dalam rangka melakukan pekerjaannya.

e) Profesionalisasi menunjuk pada peningkatan kualifikasi maupun kemampuan para anggota profesi dalam mencapai kriteria yang standar dalam penampilannya sebagai anggota suatu profesi. Profesionalisasi pada dasarnya merupakan serangkain proses pengembangan professional (professional development), baik dilakukan melalui pendidikan dan latihan "prajabatan" maupun "dalam jabatan". ${ }^{10}$

Selanjutnya profesionalisme menunjuk pada derajat penampilan seseorang sebagai profesionalis, atau penampilan suatu pekerjaan sebagai profesi, ada yang profesionalismenya tinggi, sedang dan rendah. Profesionalisme juga mengacu kepada sikap dan komitmen anggota profesi untuk bekerja berdasarkan standar yag tinggi dan kode etik profesinya. ${ }^{11}$

Jadi professional menunjuk kepada orang yang menyandang profesi dan juga menunjuk kepada penampilan seseorang dalam melakukan pekerjaannya yang sesuai dengan profesinya.

\section{2) Memiliki Kompetensi}

Suatu kompetensi ditunjukkan oleh penampilan atau unjuk kerja yang dapat dipertanggungjawabkan (rasional) dalam upaya mencapai suatu tujuan. Sehubungan dengan itu Sanjaya ${ }^{12}$ mengemukakan bahwa sebagai suatu Profesi, terdapat sejumlah kompetensi yang dimiliki oleh seorang guru, yaitu meliputi kompetensi pribadi, kompetensi professional, kompetensi sosial kemasyarakatan, dan kompetensi pedagogis.

\section{a) Kompetensi Pribadi}

Guru sebagai seorang panutan atau model, harus mempunyai kompetensi yang berhubungan dengan pengembangan kepribadian (personal competence), di antaranya:

(1) Kemampuan yang berhubungan dengan pengamalan ajaran agama sesuai dengan keyakinan agama yang dianutnya.

(2) Kemampuan untuk menghormati dan menghargai antar umat beragama

(3) Kemampuan untuk berperilaku sesuai dengan norma, aturan, dan sistem nilai yang berlaku di masyarakat.

${ }^{10}$ Djouhari Kansil, Disertasi Kompetensi Guru Bersertifikasi di SULUT, (Malang: UNMER, 2011), 7

11 Ibid.

${ }^{12}$ Wina Sanjaya, Strategi ....., 18-19 
(4) Mengembangkan sifat-sifat yang terpuji sebagai seorang guru, misalnya, sopan-santun dan tata krama.

(5) Bersifat demokratis dan terbuka terhadap pembaruan dan kritik.

\section{b) Kompetensi Profesional}

Kompetensi adalah kemampuan yang berhubungan dengan penyelesaian tugastugas keguruan. Tingkat profesional seorang guru dapat dilihat dari kompetensi ini. Beberapa kemampuan yang berhubungan dengan kompetensi ini di antaranya:

(1) Kemampuan untuk menguasai landasan pendidikan, misalnya paham akan tujuan pendidikan yang harus dicapai, baik tujuan nasional, tujuan institusional, tujuan kurikuler, tujuan pembelajaran.

(2) Pemahaman dalam bidang psikologi pendidikan, misalnya paham tentang tahapan perkembangan siswa, paham tentang teori-teori belajar, dll.

(3) Kemampuan dalam penguasaan materi pelajaran sesuai dengan bidang studi yang diajarkannya.

(4) Kemampuan dalam mengaplikasikan berbagai metodologi dan strategi pembelajaran.

(5) Kemampuan merancang dan memanfaatkan berbagai media dan sumber belajar.

(6) Kemampuan dalam melaksanakan evaluasi pembelajaran.

(7) Kemampuan dalam menyusun program pembelajaran.

(8) Kemampuan dalam melaksanakan unsur-unsur penunjang, misalnya: paham akan administrasi sekolah, bimbingan, dan penyuluhan.

(9) Kemampuan dalam melaksakan penelitian dan berpikir ilmiah untuk meningkatkan kinerjanya.

\section{c) Kompetensi Sosial Kemasyarakatan}

Kompetensi ini berhubungan dengan kemampuan guru sebagai anggota masyarakat dan sebagai makhluk sosial, yang meliputi:

(1) Kemampuan untuk berinteraksi dan berkomunikasi dengan teman sejawat untuk meningkatkan kemampuan profesional.

(2) Kemampuan untuk mengenal dan memahami fungsi-fungsi setiap lembaga kemasyarakatan.

(3) Kemampuan untuk menjalin kerjasama, baik secara individual maupun secara kelompok.

\section{d) Kompetensi Pedagogis}

Kompetensi pedagogis merupakan kemampuan guru dalam pengelolaan pembelajaran peserta didik, yang sekurang-kurangnya meliputi:

(1) Pemahaman wawasan atau landasan pendidikan

(2) Pemahaman terhadap peserta didik

(3) Pengembangan Kurikulum/Silabus

(4) Perancangan Pembelajaran 
(5) Pelaksanaan pembelajaran yang mendidik dan dialogis

(6) Pemanfaatan teknologi pembelajaran

(7) Evaluasi hasil belajar

(8) Pengembangan peserta didik untuk mengaktualisasikan berbagai potensi yang dimiliki. ${ }^{13}$

Mengajar bukan sekedar menyampaikan materi pelajaran, tetapi suatu proses yang mengubah perilaku siswa agar siswa sesuai dengan tujuan yang diharapkan. Oleh karena itu seorang guru perlu memiliki kemampuan merancang dan mengimplementasikan berbagai strategi pembelajaran yang dianggap cocok dengan minat dan bakat serta sesuai dengan taraf perkembangan siswa termasuk di dalamnya memanfaatkan berbagai sumber dan media pembelajaran untuk menjamin efektifitas pembelajaran, seperti halnya pernyataan James Cooper yang dikutip Sanjaya sebagai berikut: "A teacher is person charged with the responsibility of helping others to learn and to behave in new different ways" "It Itulah sebabnya profesi guru adalah pekerjaan profesional yang membutuhkan kemampuan khusus, supaya dapat mencapai hasil sesuai proses pendidikan yang dilaksanakan oleh lembaga pendidikan keguruan, sehingga seorang guru memerlukan kompetensi kepribadian, kompetensi professional, kompetensi pedagogis dan kompetensi sosial kemasyarakatan, untuk pencapaian proses pendidikan.

\section{BAB II}

\section{YESUS SOSOK GURU AGUNG}

Dalam sejarah gereja membuktikan, bahwa Alkitab selalu menjadi sumber utama atau pusat pendidikan gereja. Umat Kristiani percaya bahwa Allah menyatakan diri-Nya dalam sejarah ciptaan-Nya dan percaya bahwa Allah secara khusus menyatakan diri-Nya dalam Alkitab. Menurut M. Luther, ada empat dasar teologi yang menjadi landasan bagi teori dan praktek Pendidikan Agama Kristen, yakni:

a) Keadaan berdosa dari setiap orang, karena itu setiap orang harus mendapatkan Pendidikan Kristen. Dengan percaya pada perbuatan Allah dalam Kristus Yesus, maka semua orang dikaruniai kekuatan yang mengatasi akibat buruk yang berlangsung dalam dirinya karena tabiatnya yang berdosa.

b) Pembenaran oleh iman. Dosa telah meresap ke dalam semua kebajikan insani di samping tindakannya yang buruk. Jadi, dampaknya mengendalikan segala

13 Wina Sanjaya, Strategi ....., band. uraian mengenai kompetensi guru yang mencakup Kompetensi Pedagogis, Kompetensi Pribadi, Kompetensi Profesional dan Kompetensi Sosial Kemasyarakatan tertuang juga di dalam UU. No. 14 Tahun 2005 tentang Guru dan Dosen pasal 10

${ }^{14}$ Ibid., 15 
kegiatan yang diprakarsai manusia termasuk Pendidikan Kristen. Oleh karena itu mutlak diperhatikan oleh pendidik di kalangan Gereja. Dengan menerima kenyataan pembenaran karena iman, maka ada hubungan baru antara manusia dengan Allah, yaitu hubungan kepercayaan kepada Allah dan kasih pada sesamanya. Sesudah dimerdekakan dalam Kristus, setiap warga perlu belajar bagaimana melayani sesama. Ajaran dasariah itu menjadi motivasi untuk melaksanakan pendidikan di kalangan jemaat dan sebagian isi kurikulumnya.

c) Imamat semua orang percaya. Semua orang Kristen mempunyai hak istimewa, karena orang yang dibenarkan karena iman telah dijadikan manusia baru dalam Yesus Kristus. Artinya setiap warga adalah imam bagi warga seimannya.

d) Firman Allah. Ada tiga arti istilah Firman Allah menurut Luther yaitu: Yesus Kristus adalah Firman Allah sendiri (Yesus secara pribadi dan ajaran-Nya adalah Firman Allah); Alkitab sebagai Firman; Firman sebagai Amanat Allah yang diberitakan kepada para warga Gereja. ${ }^{15}$ yakni:

Menurut J. Calvin ada lima dasar teologi pokok Pendidikan Agama Kristen,

a) Kedaulatan Allah. Dalam kedaulatan-Nya Dia menyatakan diri-Nya sebagai tiga Pribadi: Bapa, Anak, dan Roh Kudus.

b) Alkitab sebagai Firman Allah. Jadi Alkitab menjadi isi pokok Pendidikan Agama Kristen di kalangan jemaat dan tolok ukur yang harus dipakai untuk menyoroti proses pelaksanaan pembinaan semua warga Kristen serta menilai pelayanan apa pun di kalangan jemaat termasuk pelayanan pedagogis.

c) Ajaran tentang manusia dibagi dalam dua hal yaitu, yang pertama manusia sebagai makhluk ciptaan segambar dengan Allah dan yang kemudian jatuh ke dalam dosa; dan kedua adalah sejumlah manusia ini telah dipilih dalam Kristus Yesus untuk diselamatkan dari akibat kejatuhannya, agar mengejawantahkan buah keselamatan dalam kehidupan dan pelayanan terhadap sesamanya.

d) Ajaran tentang Gereja. Calvin mengutamakan ke-Am-an gereja. Pendidikan Agama Kristen, pemberitaan Firman dan kebaktian, termasuk penerimaan Perjamuan Kudus dimaksudkan untuk kesehatan rohani warga jemaat. Jadi Gereja adalah persekutuan kaum terpilih dalam Yesus Kristus yang dididik melalui sarana kebaktian, yang pada pokoknya adalah pemberitaan Firman dan sakramen Baptisan serta Perjamuan Kudus dan kesempatan belajar lainnya, agar kaum percaya itu mengejewantahkan pemilihannya dalam tindakan-tindakan kasih demi sesamanya manusia.

e) Ajaran tentang hubungan Gereja dan Negara. Gereja sebagai persekutuan Kristen wajib melibatkan diri dalam semua medan hubungan insani dan juga

${ }^{15}$ Roberth Boehlke, Sejarah Perkembangan Pikiran dan Praktek Pendidikan Agama Kristen, (Jakarta: BPK Gunung Mulia, 2002), 321-335 
untuk mendidik setiap warga jemaat agar menaklukkan diri kepada Firman Allah. ${ }^{16}$

Lumintang menguraikan bahwa teologi Pendidikan Agama Kristen adalah teologi yang teistik, artinya teologi yang mengemukakan mengenai Allah yang transenden dan sekaligus imanen.Teologi yang teistik ini menjadi jiwa Pendidikan Agama Kristen. ${ }^{17}$ Teologi Kristen yang teistik ini tidak hanya mengupayakan hal-hal teoritis, melainkan juga hal-hal yang praktikal, tidak hanya berlaku pada kelompok orang tertentu, melainkan untuk semua orang dan kelompok orang. ${ }^{18}$ Selanjutnya, Tanya mengutip Sara Little mengenai peranan teologi dalam Pendidikan Agama Kristen, yakni:

a) "Theology as content", teologi sebagai isi pengajaran Gereja, harus dikomunikasikan dan diwariskan serta dirumuskan secara teologis (hakekat keselamatan, kehidupan kekal, sikap-sikap Kristen, nilai-nilai Kristen). Dan apabila teologi diabaikan maka Pendidikan Agama Kristen kehilangan identitas dan misinya.

b) "Theology as norm", teologi sebagai norma, di sini si pendidik agama Kristen berfungsi sebagai teolog yang memeriksa dan menilai azas-azas kurikulum dan praktek-praktek pelayanan pedagogis Gereja.

c) "Theology as irrelevant", teologi tidak punya relevansi, kemungkinan intinya bertolak belakang dengan kemungkinan pertama, karena menurut kemungkinan ini, kebenaran apa pun ditentukan oleh fungsinya. Mereka beranggapan bahwa pendidikan itu sendiri adalah agama atau teologi.

d) "Doing theology as educating". Berteologi sebagai usaha pendidikan, dengan asumsi bahwa Allah masih aktif dalam sejarah manusia, dan cara untuk dididik adalah untuk menyelidiki arti yang ada dalam setiap peristiwa, dengan melihat bahwa di dalam semuanya, ada kehadiran Allah, dan semua peristiwa masa lampau bertalian dengan peristiwa yang akan datang.

e) "Dialogue between theology and educating". Teologi dalam dialog dengan disiplin ilmu lainnya, misalnya pedagogi, psikologi, sosiologi, filsafat, dan ilmu komunikasi. Pemanfaatan secara kritis ilmu-ilmu sosial dapat memberikan sumbang sih yang besar bagi pendidikan di Gereja, terutama dalam prosedurprosedur pedagogis, supervisi bagaimana menganalisa tingkah laku pedagogi atau menilai hasil-hasil pengajaran. ${ }^{19}$

\footnotetext{
${ }^{16}$ Robert Boehlke, Sejarah Perkembangan ....., 384-410

${ }^{17}$ Stevri I. Lumintang, Dasar-dasar Teologi Pendidikan Kristen, (Batu: Departemen Literatur, 2004), 12

${ }^{18}$ Ibid., 13

19 Elly Tanya, Gereja dan Pendidikan Agama Kristen, (Bandung: STT Cipanas, 2006),18; Band. Stevri I. Lumintang, Dasar-dasar Teologi Pendidikan Agama Kristen, (Batu: bahan ajar Christian Education dalam program Pascasarjana, 2004), 15
} 
Pendidikan Kristen merupakan disiplin ilmu terapan, yaitu disiplin ilmu yang menerapkan teologi Kristen, atau Alkitab. Teologi atau pemahaman Alkitab berperan dalam pengembangan teori dan praktek Pendidikan Agama Kristen.

\section{Kompetensi Guru Pendidikan Agama Kristen}

Keberadaan guru PAK mengacu pada pribadi Tuhan Yesus sebagai Guru Agung. Charles H. Bens mengindikasikan lima cara Tuhan Yesus mendemontrasikan diri sebagai sosok Guru Agung, yaitu:

a) Dalam Injil Lukas 4:16-20, Tuhan Yesus mendemontrasikan bagaimana Ia memilih dan membaca bagian Alkitab yang menggugah seseorang sesuai dengan situasi (tuntutan konteks). Dalam peristiwa itu, Yesus mampu menangkap apa yang dibutuhkan oleh orang-orang yang ada dalam Bait Allah itu berkaitan dengan pengajaran Firman Tuhan. Maka Dia pun memilih pembacaan Alkitab dengan mengutip dari Nabi Yesaya untuk memenuhi kebutuhan dan harapan spiritual orang-orang yang datang ke Bait Allah untuk beribadah.

b) Tuhan Yesus tidak hanya mengajar melalui kata-kata, tetapi Ia juga menulis pada saat tertentu seperti yang dilakukan-Nya ketika kepada-Nya diajukan pertanyaan mengenai seorang perempuan berzinah. Ia kemudian berkata: "Barangsiapa di antara kamu, tidak berdosa, hendaklah ia yang pertama melemparkan batu kepada perempuan itu (Yoh. 8)

c) Tuhan Yesus menguasai bahasa Ibrani dan bahasa Aram dengan baik. Dia tahu bahwa pendekatan budaya sangat penting dalam rangka menanamkan pengajaranNya, dan mereka pun bersimpati pada pengajaran-Nya.

d) Tuhan Yesus memahami dengan sangat mendalam seluruh bagian Kitab Taurat.

e) Tuhan Yesus memahami dan menghargai tradisi yang hidup dalam masyarakat Yahudi, tetapi juga mengimbanginya dengan hukum tak tertulis seperti yang tercatat dalam Injil Matius 5:21,27,31,38,43. ${ }^{20}$

Selanjutnya, Blandina merinci uraian kompetensi guru Pendidikan Agama Kristen sebagai berikut:

a) Mampu memahami isi Alkitab secara baik dan benar. Guru PAK tidak menafsir Alkitab menurut tuntutan kepentingan tertentu, tetapi mempertimbangkan latar belakang teks dan konteks. Adalah kekeliruan jika guru menerjemahkan berita Alkitab secara hurufiah tanpa belajar secara lebih mendalam mengenai konteks. Konteks adalah latar belakang sebuat teks Alkitab

${ }^{20}$ Clarence H. Benson, A Popular History of Christian Education, (Chicago: Moody Press, 1973), 25 
ditulis, situasi sosial, budaya, keagamaan ketika teks ditulis, dan tujuan penulisan teks.

b) Mampu menjembatani antara persoalan sehari-hari yang dihadapi peserta didik dengan berita Alkitab. Bahan pelajaran Pendidikan Agama Kristen yang diperoleh peserta didik dapat bermanfaat manakala bersentuhan dengan kehidupan sehari-hari peserta didik. Pendidikan iman yang diperoleh hendaknya dijadikan pisau analisis bagi peserta didik dalam membantu mereka menghadapi serta menyelesaikan berbagai persoalan yang dihadapi guru, untuk menjembatani antara pendidikan iman dengan persoalan hidup sehari-hari. Jika berita Alkitab tidak dibawa pada implikasi kehidupan sehari-hari, maka dengan sendirinya Kabar Baik yang dibawa oleh berita itu menjadi tidak berguna. Adalah merupakan tugas guru Pendidikan Agama Kristen untuk menghasilkan relevansi antara berita Alkitab dengan kehidupan sehari-hari peserta didik.

c) Menguasai bahan ajar. Bahan ajar yang disampaikan kepada peserta didik harus terlebih dulu dikuasai dan dihayati oleh guru. Hendaknya guru memahami makna tiap topik yang diajarkan sehingga mampu membagikannya kepada peserta didik. Bahan yang dikuasai dengan baik akan dapat dikomunikasikan secara baik kepada peserta didik.

d) Menguasai prinsip-prinsip pendidikan. Prinsip-prinsip pendidikan secara umum harus dikuasai oleh guru menyangkut dimensi hubungan antar guru dengan peserta didik, juga hakekat belajar-mengajar Pendidikan Agama Kristen di sekolah.

e) Mampu mengelola program belajar-mengajar. Program belajar-mengajar terutama mencakup langkah pembelajaran, harus dikuasai dengan baik sehingga guru dapat mengelola kelas, terutama ketika berhadapan dengan situasi tertentu yang tidak diduga sebelumnya. Penguasaan program belajar-mengajar memperkuat guru untuk bersikap fleksibel dalam mengatur program belajarmengajar sesuai situasi dan kondisi.

f) Mampu menggunakan media dan sumber belajar dalam rangka keberhasilan proses belajar-mengajar. Penggunaan media pembelajaran dan sumber belajar yang beragam merupakan cara cerdas yang dapat menghasilkan kelas yang selalu baru pada tiap kali pertemuan. Penggunaan media dan sumber belajar harus disesuaikan dengan situasi kelas dan topik pembahasan supaya seluruh proses pembelajaran saling berkaitan dengan kompetensi pembelajaran.

g) Mampu mengelola kelas. Keberhasilan proses belajar-mengajar sangat ditentukan oleh kemampuan guru mengelola kelas. Pengelolaan kelas termasuk di dalamnya memahami karakteristik siswa ketika peserta didik jenuh, lesu, dan kurang memahami topik yang disampaikan.

h) Mampu membangun interaksi positif antara pengajar dengan peserta didik. Keberhasilan proses belajar-mengajar turut ditentukan oleh kemampuan guru membangun interaksi positif dengan peserta didik. Dalam proses belajar-mengajar 
Pendidikan Agama Kristen, di mana pencapaian kompentesi nampak melalui adatidaknya transformasi nilai-nilai kehidupan.

i) Mampu membimbing dan mendampingi peserta didik dalam proses mencapai transformasi nilai-nilai kehidupan sebagai murid Yesus. Pembelajaran Pendidikan Agama Kristen yang disampaikan oleh guru hendaknya memiliki makna bagi peserta didik. Makna itu yang membimbing peserta didik pada pemahaman bahwa mereka adalah murid Yesus Kristus, dan karena itu kehidupan dan tingkah laku serta cara berpikir mereka harus dapat menunjukkan bahwa mereka adalah murid Yesus Kristus.

j) Mampu menggunakan berbagai hasil penelitian demi peningkatan visi dan kemampuan pengembangan metodologi dalam mengajar. $\mathrm{Di}$ bidang pendidikan terjadi reformasi secara terus menerus karena para pakar pendidikan dan psikologi giat mengadakan penelitian. Ada cukup banyak jurnal ilmiah yang mempromosikan berbagai hasil penelitian di dunia ini. Hal itu lebih mudah dicapai melalui internet dengan mengakses website pendidikan dan research atau penelitian. Guru dapat mengkaji dan mempelajari berbagai hasil penelitian yang dapat dipilih dan diseleksi sesuai dengan kebutuhan, untuk kepentingan visi dan skills atau kemampuan mengajar.

k) Mampu menguasai Prinsip-prinsip Evaluasi Belajar. Penguasaan terhadap evaluasi belajar terutama mencakup: konsep, evaluasi belajar, memilih dan mengembangkan metode evaluasi yang sesuai dengan kompetensi, indikator, dan materi, melaksanakan evaluasi belajar sesuai dengan rancangan, menganalisa hasil evaluasi untuk kepentingan peningkatan mutu proses belajar-mengajar.

l) Mampu mengembangkan karakter dan integritas yang baik. Seorang pengajar Pendidikan Agama Kristen haruslah pengajar yang memiliki karakter dan integritas yang baik karena seluruh kehidupan pengajar Pendidikan Agama Kristen merupakan contoh bagi peserta didiknya. ${ }^{21}$

Searah dengan kompetensi guru, menurut Tilaar yang mengemukakan bahwa guru profesional memiliki ciri-ciri sebagai berikut: (1) memahami dirinya dengan baik; (2) berkembang dalam keilmuan yang kuat (dalam bidang studi yang diajarkannya); (3) mengerti minat anak didik dan tahu bagaimana mengembangkannya; (4) mengembangkan tugas secara kreatif. ${ }^{22}$

Dari uraian di atas menjelaskan tentang kompetensi yang harus dimiliki oleh seorang guru Pendidikan Agama Kristen berdasarkan Kurikulum Berbasis Kompetensi, sehingga tugas guru dalam pendidikan agama sangat penting dan tanggung jawabnya berat.

21 Janse Belandina Non Serrano, Profesionalisme Guru dan Bingkai Materi. (Bandung: Bina Media Informasi, 2009), 47-52

22 H.A.R. Tilaar, Pengembangan Sumber Daya Manusia dalam Era Globalisasi: Visi, Misi, dan Program Aksi Pendidikan dan Pelatihan Menuju 2000, (Jakarta: Gramedia, 1998), 279-302 


\section{BAB III \\ GURU PENDIDIKAN AGAMA KRISTEN}

Pada bab tiga ini penulis akan membahas tentang Guru Pendidikan Agama Kristen, dengan pokok-pokok bahasan sebagai berikut:

\section{Syarat-syarat Guru Pendidikan Agama Kristen}

Mengingat tugas guru dalam pendidikan agama sangat penting serta tanggung jawanya cukup berat, maka seorang guru Pendidikan Agama Kristen harus memenuhi syarat-syarat berikut:

(1) Seorang guru harus mempunyai pengalaman rohani. Perlu sekali ia sendiri mengenal Tuhan Yesus. Hatinya harus dijamah Tuhan dan diterangi oleh Roh Kudus.

(2) Seorang guru harus mempunyai hasrat sejati untuk menyampaikan Injil kepada sesama manusia. Harus ada dorongan yang kuat untuk mengantar orang lain kepada Yesus Kristus.

(3) Seorang guru harus mempunyai pengetahuan yang cukup tentang isi iman Kristen. Ia harus mengenal Alkitab dengan baik. Untuk itu ia perlu dididik sebelum mengajar orang lain.

(4) Seorang guru perlu mengetahui bagaimana iman bertumbuh dalam batin manusia dan bagaimana iman itu berkembang dalam seluruh hidup orang percaya itu.

(5) Seorang guru harus menunjukkan kesetiaan yang sungguh kepada gerejanya. Ia sendiri harus rajin mengambil bagian dalam kebaktian dan terlibat dalam pelayanan gerejanya.

(6) Seorang guru harus memiliki kepribadian yang jujur. ${ }^{23}$

\section{Peranan Guru Pendidikan Agama Kristen}

Ketika mengajar, guru memainkan peran dan fungsi sosial karena berinteraksi dengan anak didik, rekan kerja dan masyarakat di luar ruang pembelajaran. Sebaliknya ketika belajar, anak didik juga memainkan peran sosial, yang membuatnya dapat berinteraksi dan berkomunikasi dengan rekan-rekannya serta dengan gurunya. Baik-buruknya komunikasi yang diperankan oleh guru memengaruhi prestasi belajar anak didik. ${ }^{24}$ Berikut adalah pembahasan tentang peran guru di dalam menunaikan tugas dan panggilannya yakni:

${ }^{23}$ E.G. Homrighausen \& I.H Enklaar, Pendidikan Agama Kristen, (Jakarta: BPK Gunung Mulia, 2001), 165-167

${ }^{24}$ Anthony Michael, Introducing, Christian Education, (Grand Rapids: Mic. Baker Academic, 2001), 45 
(1) Guru Sebagai Pendidik. Dalam peran sebagai pendidik, perlengkapan yang diberikan guru kepada anak didik bukan hanya pengetahuan kognitif, melainkan juga pemahaman afektif, moral, serta spiritual. Sebagai pendidik, guru menaruh perhatian pada pembentukan watak dan moral peserta didik. Bukan hanya moral pribadi yang dikembangkan, melainkan juga termasuk moral sosial dan moral terhadap lingkungan kehidupan. ${ }^{25}$ Selanjutnya bila guru Pendidikan Agama Kristen berperan sebagai pendidik, ia tidak melihat tugasnya itu hanya sebatas mengajarkan kekristenan sebagai pengetahuan agama, tetapi juga sebagai kehidupan (life). Iman Kristen sendiri berbicara mengenai hidup (bahasa Yunani: Zoe) yang memerdekakan, yang diberikan oleh Tuhan Yesus Kristus (Yoh 1:4; 10:10; 14:6). ${ }^{26}$ Searah dengan itu Stubblefield berpendapat, bahwa Guru Kristen sebagai pendidik, haruslah meneladani Yesus Kristus, Guru Agung. ${ }^{27}$

(2) Guru Sebagai Pengajar dan Pembelajar. Dalam peran sebagai pengajar, guru mengelola kegiatan agar peserta didiknya belajar (teaching for learning). Untuk itu ia harus selalu melakukan persiapan, merencanakan tujuan dan kompetensi yang menjadi arah pembelajaran. Dalam persiapan itu, guru merencanakan strategi dan metode pembelajaran, memilih dan menetapkan sumber serta media pembelajaran yang efektif guna mewujudkan tujuan. Itulah sebabnya, guru harus selalu meningkatkan kualitas pengetahuannya, baik secara formal maupun informal. ${ }^{28}$ Sebagai pembelajar, ${ }^{29}$ guru patut semakin mendalami bidang studi yang diajarkannya, dengan giat membaca atau mengikuti pendidikan nonformal (seminar, forum diskusi, lokakarya, kursus dan sejenisnya).

(3) Guru Sebagai Pelatih. Pengajaran (Teaching) kerap diartikan sebagai pemberian informasi, memberi tekanan pada pembentukan wawasan dan pengetahuan kognitif. Adapun pelatihan (training) merupakan bagian dari pengajaran dan pendidikan. Pelatihan lebih berfokus pada pembentukan keterampilan dasar, menengah, dan lanjutan, sehingga peserta didik bertumbuh dari amatir menjadi handal atau cekatan. Untuk dapat mengerjakan pelatihan, guru harus memahami bentuk dan jenis keterampilan yang harus dikembangkan peserta didik. Pelatih yang baik, biasanya menerapkan prinsip reinforcement yaitu memberikan pujian bagi murid yang berhasil melakukan kegiatan tertentu sesuai dengan standar untuk memperkuat motivasi berikutnya. ${ }^{30}$ Searah dengan itu dalam kitab Injil,

\footnotetext{
${ }^{25}$ B.S. Sijabat, Mengajar Secara ..., 102

26 Ibid.

27 Jerry Stubblefield, The Efecive Minister of Education A Comprehensive, (Handbook, Broadman \& Holman Publisherrs, 1993), 56

${ }^{28}$ B.S. Sidjabat, Mengajar Secara ......., 106. Band. Howard Hendriks, Teaching to Change Lives, (Portland, Oregon: Mulnomah Press, 1987), 17. Guru harus menjadi manusia pembelajar. Kalau tidak, maka perubahan pengetahuan, sikap, nilai hidup dan spiritualitasnya mandeg, akibatnya murid kurang menemukan inovasi dari interaksi pembelajaran.

29 Andrias Harefa, Menjadi Manusia Pembelajar, (Penerbit Harian Kompas, 2000), secara panjang lebar memberikan usulan bagaimana guru seharusnya berperan sebagai pembelajar di samping tugas mengajar. Dengan dimotivasi oleh kesadaran, maka guru dapat meningkatkan kualitasnya dengan beragam cara kreatif. Hasil pembelajaran itu akan menjadi masukan berharga bagi anak didiknya.

30 B.S. Sidjabat, Mengajar Secara ...., 110
} 
Yesus Sang Guru, juga berperan sebagai pelatih. Ia menjadi contoh atau model di hadapan murid-murid dalam hal berkhotbah, memberi penjelasan, menjawab pertanyaan dan menolong orang-orang sakit. Yesus melibatkan mereka di dalam melayani banyak orang, termasuk ketika memberi makan 5000 dan 4000 orang. Yesus menugaskan murid-murid untuk melakukan praktik pelayanan. Ketika pulang, Yesus mengambil waktu untuk mendengarkan laporan pengalaman mereka. Pada saat itu Yesus menyatakan pandangan-Nya, meneguhkan dan mengoreksi. Hasilnya murid-murid menjadi pemberita Injil. ${ }^{31}$

(4) Guru Sebagai Fasilitator. Peran guru sebagai fasilitator, ialah guru berusaha memahami kebutuhan atau keperluan peserta didik dalam proses belajar. Ia perlu bertanya kepada mereka mengajukan kasus-kasus kecil untuk ditanggapi dalam rangka mengukur pemahaman anak didik. Dari keadaan itulah guru melakukan bimbingan belajar. ${ }^{32}$ Dalam konteks pembinaan warga Gereja, peran guru sebagai fasilitator sangat dibutuhkan. Sebagai guru dituntut untuk memfasilitasi pertemuan, termasuk mengelola suasana interaktif agar menyenangkan, juga menyiapkan sumber dan media belajar pada saat warga jemaat melakukan kegiatan pendalaman Alkitab, termasuk mempersiapkan makanan ringan. ${ }^{33}$

(5) Guru Sebagai Motivator. Peran guru sebagai motivator itu sangat mendasar, mengingat peristiwa belajar pada prinsipnya berlangsung dalam diri peserta didik. Peserta didik merupakan pelaku proses belajar bagi dirinya sendiri. Ucapan-ucapan yang membangun dari guru akan membangunkan semangat anak didik. Menurut Yount, jika guru dipandang oleh murid berperan sebagai sahabat yang selalu sedia ditemui, memiliki jiwa mengasuh, hangat, tidak kaku atau fleksibel dan dewasa secara emosi, maka peserta didik akan termotivasi. ${ }^{34}$ Peserta didik rindu melihat gurunya yang ramah dan berwibawa. Remaja dan pemuda pada umumnya merindukan teladan iman dan moral yang berdisiplin serta konsisten. Alkitab mengungkapkan bahwa Rasul Paulus pun menasihati Titus supaya menjadi teladan di kalangan kaum muda (Tit. 2:6-7). Timotius dipesankan Paulus menjadi teladan bagi semua orang (1 Tim. 4:12). ${ }^{35}$ Searah dengan itu pertolongan Tuhan sangat dibutuhkan guru di dalam memotivasi peserta didik, secara khusus ketika mempelajari Alkitab. Roh Kudus-lah motivator dalam kehidupan orang percaya (Yoh. 14:16-17,26). Untuk menikmati intervensi Roh itu, maka guru perlu mengajak peserta didik untuk sungguh-sungguh menyerahkan kegiatan belajar-mengajar melalui saat teduh, doa, atau ibadah singkat. ${ }^{36}$

(6) Guru Sebagai Pemimpin. Sebagai pemimpin, tugas guru ialah mengelola terjadinya peristiwa belajar. Artinya guru bertindak juga sebagai Classroom

31 Ibid.

32 Ibid., 112

${ }^{33}$ Ibid.

${ }^{34}$ William Rick Yount, Called to Teach; an Introduction to Ministry of Teaching, (Broadman \& Holman Publishers, 1998), 76

${ }^{35}$ B.S Sidjabat, Mengajar Secara ..., 114

${ }^{36}$ Ibid. 
Manager. Pertama-tama tugas guru ialah environmentalist, yang mengelola lingkungan belajar supaya kondusif. Lingkungan yang dimaksud itu termasuk ruangan, suasana emosi yang nyaman, serta relasi yang hangat dan bersahabat. ${ }^{37}$ Agar efektif sebagai pemimpin, guru perlu menempatkan dirinya sebagai figur otoritas (authoritative) tanpa harus berperilaku secara otoriter (authoritarian). Berkaitan dengan guru sebagai pemimpin, Sidjabat memberikan pendapat ada empat model guru sebagai pemimpin yakni:

[1] model guru partisipatif, yang lebih mengutamakan relasi yang baik dengan peserta didik dari pada mencapai tujuan pengajaran.

[2] guru model otoriter, yang lebih mengutamakan penegakan disiplin dan pencapaian tujuan daripada pembinaan relasi.

[3] model guru kurang peduli artinya kurang melakukan tugas dengan sepenuh hati, baik dalam segi pembinaan relasi maupun dalam segi pencapaian tujuan.

[4] guru yang menekankan pencapaian keduanya secara seimbang yaitu pengutamaan relasi dan pencapaian tujuan. ${ }^{38}$

Searah dengan itu peran guru sebagai pemimpin sudah diteladankan oleh Tuhan Yesus Sang Guru Agung, sebagaimana dijelaskan dalam kitab Injil (Mrk. 10:4445), bahkan dilaporkan bahwa Yesus sebagai Guru bersedia membasuh kaki murid-murid-Nya (Yoh 13: 3-17).

(7) Guru Sebagai Komunikator. Sebagai komunikator, tugas guru yang utama ialah memberi penilaian atas kemajuan belajar peserta didik. Dengan bijak ia menyampaikan informasi yang berguna bagi peserta didik. Pentingnya komunikasi yang membangun itu dapat dipelajari dari nasihat Rasul Paulus kepada jemaat Efesus, "janganlah ada perkataan kotor yang keluar dari mulutmu, tetapi pakailah perkataan yang baik untuk membangun di mana perlu, supaya mereka yang mendengarnya, beroleh kasih karunia" (Ef. 4:29). Dengan perkataannya, guru dapat memberikan harapan, tetapi pada saat yang sama juga dapat menimbulkan kekecewaan. ${ }^{39}$

(8) Guru Sebagai Agen Sosialisasi. Sebagai agen sosialisasi, guru berupaya membantu peserta didik untuk mengalami interaksi edukatif yang menyenangkan, yang didalamnya mereka lebih saling mengenal dan saling mengisi, serta kerap melakukan diskusi dan kerja kelompok. Searah dengan itu Mursell dan Nasution berpendapat bahwa makna dan efektifitas pelajaran untuk sebagian besar tergantung pada rangka dan suasana sosial di tempat pelajaran itu diberikan, atau dengan kerja kelompok, maka makna dan efektifitas pelajaran dapat ditingkatkan. ${ }^{40}$

(9) Guru Sebagai Pembimbing. Sebagai pembimbing atau konselor guru PAK mendengar kegelisahan dan persoalan muridnya, lalu bersama-sama mencari

\footnotetext{
${ }^{37}$ William R. Yount, Called to Teach:....., 157

38 B.S Sidjabat, Mengajar secara ...., 114-117

39 Ibid., 120

40 J. Murshell \& S Nasution, Mengajar dengan Sukses, (Bandung: Jemmars, 2001), 165
} 
upaya mengatasinya dalam terang Firman Tuhan serta pertolongan Roh Kudus. Patokan nilai di dalam konseling secara Kristen adalah Firman Allah. Dengan demikian, nasihat yang diberikan guru kepada peserta didiknya itu bersumber dari Firman Tuhan karena Allah memakai Firman-Nya untuk mengoreksi, mendidik, serta memperbaiki sikap dan perilaku. ${ }^{41}$ Searah dengan itu guru tidak boleh memanipulasi anak didik yang meminta bimbingan dan penyuluhan agar selalu bergantung (dependent) kepadanya, sebab tujuan konseling haruslah memampukan mereka yang dibimbing menghadapi dan menyelesaikan masalahnya secara kreatif di bawah bimbingan Tuhan. ${ }^{42}$

(10) Guru Sebagai Pemberita Injil. Rumusan Robert Boehlke mengenai tujuan Pendidikan Agama Kristen adalah menolong orang dari semua golongan usia yang dipercaya Tuhan kepada pemeliharaan Gereja untuk memberi tanggapan akan pernyataan Allah dalam Yesus Kristus, yang disaksikan dalam Alkitab dan kehidupan Gereja, supaya di bawah bimbingan Roh Kudus, mereka diperlengkapi guna melayani sesama manusia atas nama Tuhan-nya di tengahtengah keluarga, Gereja, masyarakat dan dunia. ${ }^{43}$ Searah dengan itu kurikulum Pendidikan Agama Kristen yang dikeluarkan oleh Pendidikan Nasional pada tahun 2004 menegaskan bahwa Pendidikan Agama Kristen pada dasarnya merupakan pemberitaan Injil atau Kabar Baik tentang Karya Allah Tritunggal yang menyelamatkan manusia berdosa melalui Yesus Kristus. Injil berpusat pada tugas Kristus yang mati di kayu salib untuk menebus dosa manusia, dan bahwa Ia telah dikuburkan dan dibangkitkan pada hari ketiga sesuai dengan Kitab Suci (1 Kor. 15:3-4). Sebagai penginjil, guru dapat menjelaskan Injil melalui pendekatan pribadi dan atau kelompok, yaitu memberitahukan kesaksian Alkitab mengenai fakta bahwa manusia itu berdosa sehingga terhukum, berada dalam maut, diperbudak hawa nafsu, serta mengalami penyimpangan moral. Dosa membuat hidup mereka menyimpang dari standar Allah yang kudus, namun kasih Allah telah menyatakan anugerah besar kepada manusia, yaitu melalui kematian Yesus di salib dan oleh kebangkitan-Nya dari kematian. Tanpa pembaharuan iman secara pribadi kepada Yesus Kristus, peserta didik akan cenderung mempelajari Pendidikan Agama Kristen hanya sebagai mata pelajaran kognitif semata, untuk mendapatkan nilai ujian. ${ }^{44}$

(11) Guru Sebagai "Imam dan Nabi". Yount mengemukakan bahwa guru Kristen memiliki peran sebagai pelayan, dengan tiga dimensi: nabi, imam, dan raja. Yesus sang Guru Agung juga melakukan peran Nabi, Imam, Raja. ${ }^{45}$ Sebagai imam, guru dapat menjadi "pengantara" antara anak didiknya kepada Allah untuk membawa anak didik dalam ibadah, dan melalui doa guru dapat meneladani Yesus yang berdoa (Yoh. 17). Secara teologis guru juga melakukan

${ }^{41}$ B.S. Sidjabat, Mengajar Secara ......, 123

42 Ibid, 124

43 ................... Memperlengkapi bagi Pelayanan dan Pertumbuhan, (Jakarta: BPK Gunung Mulia \& UPI STT Jakarta, 2010), 222

${ }^{44}$ B.S Sidjabat, Mengajar Secara ....., 126

${ }^{45}$ William R. Yount, Called to Teach: an Indtroduction...., 127 
peran kenabian, menyatakan kebenaran Allah untuk menegur serta mengoreksi dan mentransformasi. ${ }^{46}$

(12) Guru Sebagai Teolog. Tujuan pengajaran ialah supaya setiap anak dididik sungguh-sungguh menjadi murid Tuhan Yesus, yang rajin dan setia. Guru tidak boleh merasa puas sebelum anak didiknya menjadi orang Kristen yang sejati. ${ }^{47}$ Searah dengan uraian ini guru Pendidikan Agama Kristen perlu memahami bahwa teologi sangat berkaitan dengan pelayanannya. Teologi dapat menjadi bahan atau isi pengajarannya. Karena ketika ia mengajar, keyakinan dan pemikirannya teologisnyalah yang dikomunikasikan. Guru-guru Pendidikan Agama Kristen mengajarkan kebenaran-kebenaran teologi yang dikemas berdasarkan studi Alkitab. ${ }^{48}$ Menurut Osmer, pemikiran teologi yang dikembangkan itu hendaknya bukan untuk memuaskan akal semata, melainkan harus mampu menimbulkan sukacita dan kekaguman yang mendalam terhadap sifat, kehendak dan karya Allah. Kemampuan berteologi secara konseptual dan praktis diharapkan bukan hanya dimiliki guru, melainkan juga oleh peserta didik, hal demikian berkembang apabila guru memperlengkapi diri dengan latihan refleksi teologis sebagai hasil dari membaca, memahami, dan menafsirkan firman Allah dalam mencari kehendak-Nya. ${ }^{49}$

\section{SIMPULAN}

Guru merupakan figur penting dalam menyukseskan kegiatan belajarmengajar. Kegiatan belajar-mengajar senantiasa mengharapkan guru berkualitas. Guru berkualitas artinya berkaitan dengan iman, spiritualitas, watak, pengetahuan, kemampuan dan keterampilan. Guru Kristen perlu memahami pribadi Yesus sebagai guru yang harus diteladani dalam hidup sehari-hari dan dalam pelaksanaan tugas keguruan. Seorang guru Kristen juga perlu menyadari bahwa peranan Roh Kudus bukan hanya berlangsung dalam rangka pendewasaan iman dan kesadaran akan kesucian hidup, tetapi juga dalam rangka mengemban profesi sehari-hari. Seorang guru, sebagai pengajar iman Kristen, sudah tentu sangat memerlukan ketergantungan terhadap kuasa, urapan dan kehadiran Roh Kudus. Sebab Dia-lah yang sanggup membuka mata hati orang untuk memahami kebenaran (Ef. $3: 16,17,18) .{ }^{50}$

Guru yang berkualitas harus memahami profesi keguruan. Guru perlu meningkatkan dirinya menjadikan pribadinya sebagai instrumen yang handal di dalam Tuhan. Dalam melakukan kewenangan profesionalnya, seorang guru dituntut

${ }^{46}$ B.S Sidjabat, Mengajar secara ...., 128
${ }^{47}$ E.G. Horighausen \& I. H Enklaar, Pendidikan Agama Kristen..., 164
${ }^{48}$ B.S Sidjabat, Mengajar secara ...., 130
${ }^{49}$ Richard Osmer, Teaching as a PracticalTheology, dalam Thelogical for Empowering Christian Education, (Jack L. Seymout, Donald E.Miller Abingdon Press, 1990), 216-238. Band B.S. Sidjabat, Mengajar secara ...., 131

${ }^{50}$ B.S Sidjabat, Mengajar secara ...., 37 
memiliki kompetensi yang beraneka ragam. Guru seperti ini harus mempunyai semacam kualifikasi formal. Dengan demikian, guru PAK harus dapat melaksanakan tugas mengajar dan mendidik di bidang PAK dengan berkarakter dan berdisiplin tinggi, mampu menggunakan berbagai wacana dalam rangka mengembangkan visi dan kemampuan mengajar serta dapat mengembangkan keterampilan dengan mengikuti berbagai kegiatan pelatihan, lokakarya maupun seminar.

Jadi guru PAK yang profesional tidak hanya terpaku kepada kurikulum yang telah ditetapkan oleh Pemerintah, tetapi harus mampu mengembangkan kurikulum tersebut untuk pertumbuhan iman peserta didik. Pertumbuhan iman harus dimulai dari diri guru. Jati dirinya dalam Kristus harus terbentuk dengan kuat. Guru profesional harus dapat menghayati permasalahan yang dihadapi dalam proses pembelajaran, sehingga termotivasi, kritis dan reflektif untuk memecahkan persoalan pendidikan.

Peran guru sebagai sumber belajar merupakan peran yang sangat penting. Peran sebagai sumber belajar berkaitan erat dengan penguasaan materi pelajaran. Secara khusus dalam konteks sekolah, guru wajib memiliki kualifikasi akademik, kompentensi, sertifikasi pendidik, sehat jasmani dan rohani, sehingga profesionalitas guru PAK juga melekat pada dirinya sebagai seorang pendidik, maka termasuk di dalamnya tuntutan kompetensi dan profesional yang sama. Sedangkan salah satu cara efektif untuk menggali serta meningkatkan kemampuan tersebut adalah dengan mengevaluasi diri sendiri, secara khusus bentuk evaluasi pada materi profesionalisme guru PAK itu, mengacu pada sosok Tuhan Yesus sebagai Guru Agung. ${ }^{51}$

Dengan demikian, dapat disimpulkan bahwa hal utama bagi seorang guru PAK adalah mengajarkan Firman Allah agar siswa memiliki pedoman dalam kehidupannya, yang pada akhirnya mereka mengalami suatu perubahan, oleh karena di dalamnya terkandung maksud dari firman Allah yang bermanfaat untuk mengajar, menyatakan kesalahan, memperbaiki kelakuan, dan mendidik orang dalam kebenaran $(2 \operatorname{Tim} 3: 16)$.

\footnotetext{
${ }^{51}$ Janse Belandina Non Serrano, Profesionalisme Guru dan Bingkai Materi..., 14
} 


\section{DAFTAR PUSTAKA}

2008 Alkitab. Jakarta: Lembaga Alkitab Indonesia

Belandina Non Searrano, Janse

2009 Profesionalisme Guru dan Bingkai Materi. Bandung: Bina Media Informasi

Benson, Clarence $\mathrm{H}$.

1973 A Popular History of Christian Education. Chicago: Moody Press

Boehlke, Roberth

2002 Sejarah Perkembangan Pikiran dan Praktek Pendidikan Agama Kristen. Jakarta: BPK GunungMulia

Harefa, Andrias

2000 Menjadi Manusia Pembelajar. Penerbit Harian Kompas

Hendriks, Howard

1987 Teaching to Change Lives. Portland, Oregon: Mulnomah Press

Homrighausen, E.G. \& I.H. Enklaar

2001 Pendidikan Agama Kristen. Jakarta: BPKGunung Mulia

Kansil, Djouhari

2011 Disertasi Guru Bersertifikat di SULUT. Malang

Lumintang, Stevri Indra

2004 Dasar-dasarTeologi Kristen. Batu: STT I-3

2004 Sejarah dan Filsafat Pendidikan Agama Kristen, Diktat Pendidikan Kristen program Pascasarjana. Batu: STT I-3

Michael, Anthony

2001 Introducing, Christian Education. Grand Rapids: Mic. Baker Academic

Murshell, J \& Nasution, S

2001 Mengajar dengan Sukses. Bandung: Jemmars

Nasution, $\mathrm{S}$

1989 Kurikulum dan Pengajaran. Jakarta: PT. Bina Aksara

Nainggolan, J.M

2007 Menjadi Guru Agama Kristen. Bandung: Generasi Info Media 
Osmer, Richard

1990 Teaching as a PracticalTheology, dalam Thelogical for Empowering Christian Education. Jack L. Seymout: Donald E.Miller Abingdon Press

Sanjaya, Wina

2011 Kurikulum dan Pembelajaran. Jakarta: Prenada Media

2011 Strategi Pembelajaran Berorientasi Standar Proses Pendidikan. Jakarta: Prenada Media

Sidjabat, B.Samuel

1997 Menjadi Guru Profesional. Bandung: Yayasan Kalam Hidup

1999 Strategi Pendidikan Kristen. Yogyakarta: Andi Ofset

2010 Mengajar Secara Profesional. Bandung: Yayasan Kalam Hidup

Spencer L.M and S.M Spencer

1993 Competence at Work: Models for Superior Perfomance. New York: John Willey and Sons. Inc

Stubblefield, Jerry

1993 The Efecive Minister of Education A Comprehensive. Handbook, Broadman\&Holman Publisherrs

Tanya, Elly

2006 Gereja dan Pendidikan Agama Kristen. Cipanas: STT Cipanas

Tilaar, H.A.R

2003 Kekuasaan dan Pendidikan. Jakarta: Rineka Cipta.

Yulaelawati, Ella

2004 Kurikulum dan Pembelajaran. Bandung: Pakar Raya.

Yount, William Rick

1998 Called to Teach; An Introduction to Ministry of Teaching. Broadman\& Holman Publishers

2010 Memperlengkapi bagi Pelayanan dan Pertumbuhan. Jakarta: BPK Gunung Mulia \& UPI STT Jakarta

2004 Kerangka Dasar dan Struktur Program. Jakarta: Departemen Pendidikan Nasional 